\title{
THE ROLE OF SOCIOECONOMIC DIFFERENCES AND MATERIAL DEPRIVATION IN PEER VIOLENCE
}

\author{
Vesna Bilić \\ University of Zagreb, Faculty of Teacher Education
}

\section{Abstract}

In schools around the world in the 21st century the dominant and worrying problems are: an increase in the number of poor and financially and materially deprived and continuous increase in violence among peers, which brings us to the intriguing question whether there is a connection between these two phenomena. Therefore, the theoretical part of this paper analyzes the increase of peer violence in the context of socioeconomic inequalities of different societies which students live in and socioeconomic family factors. The aim of the empirical part is to determine which variables of socioeconomic status and material deprivation of children predict the status of perpetrators or victims of peer violence. The study included $610(44.8 \% \mathrm{M} ; 51.6 \% \mathrm{~F})$ primary school students, with average age of 13,88 years from different regions of the Republic of Croatia. For data collection the socioeconomic status questionnaire, scale of material deprivation of children in school and scale of victimization and violence among peers were used. The results indicated that $34.8 \%$ of respondents have acted violently toward peers because of their poorer financial status, and $45.7 \%$ were victimized for the same reason. It was also found that the analyzed SES variables and material deprivation do not predict committing violence against peers. Living in unfavorable socioeconomic conditions is associated with the role of victims, lower education of mothers, lower work status of the father, child's experience of fear because of the family's poor financial situation, and material deprivation in school are statistically significant predictors of victimization. It is suggested that practitioners, the public and policy makers pay attention and assist the growing number of children from socioeconomically disadvantaged families. They must be in focus of all school preventive programs, especially due to the increased risk for those children of being exposed to peer violence.

Key words: SES, deprivation, bullying, poverty, family, school 


\section{Introduction}

It seems that at the moment, in many schools around the world there are two big dominant and worrying problems: an increase in the number of poor and financially deprived children, as well as continuous increase in violence among students. The intriguing question is whether there is a connection between these two phenomena.

It was hard to assume that these would be the problems which will mark school life in the 21 st century, especially when it comes to poverty. Indeed, it was expected that poverty would be reduced or completely eradicated (Šućur, 2014), and the prominent international organizations, such as UN (Convention on the Rights of the Child) and UNICEF promised that the world will become world worthy of children (Boillet, 2002; Minujin et al., 2006), but it happened the other way around. Today, poverty is a global problem that affects one fifth of the world's population (DružićLjubotin and Ljubotina, 2014),affecting both the so called prosperous countries and the rich west. In those countries, more than half of children live in poverty (KletečkiRadović, 2011). This was particularly contributed by adverse social and economic processes at the beginning of the new millennium - recession, crisis of global proportions, social injustice, instability and insecurity around the world, especially in transition, post- socialist countries.

The number of people who do not have basic living conditions (home, food, heating, hygiene), who live in absolute poverty with their income being less than 2 dollars a day or $30 \%$ of the national income median, has increased. There is even more people who live in relative poverty and do not have a minimum decent living standard that is usual in their community or society they live in, and their income is less than $60 \%$ of national income median (Katz et al., 2007; McDonald, 2008; Neuborg et al., 2014; Šućur, 2006; 2014). With these two groups, who are traditionally described as poor, there is a growing number of the so- called new poor (Šućur, 2014). They are a product of economic crisis which hit the middle class and working population who had previously lived in relative safety. A large number of people lost their jobs and hope to find a new one, and some who work are not being paid. All this led to inability to fulfill basic needs of the family and maintain standard they were accustomed to. For these reasons, they are not able to pay back housing loans which they easily took before or pay utility bills, which resulted in debt overhangs, evictions, foreclosures and facing poverty (Šućur, 2014).

The crisis particularly affected children whose parents are not able to meet their material and non-material needs (Neubourg et al., 2014; Šućur, 2014), so they 
experience multiple deprivations which become particularly evident in school. It is necessary to say that children perceive poverty or unfavourable financial situation differently from adults, not only through lack of money, but through indicators of availability and accessibility (Neubourh et al., 2014). Due to material deprivation, lack of items (clothing, shoes, warm meals and school supplies), access to activities that most people consider necessary (extracurricular activities, sports, language learning, tutoring, etc.) and limited opportunities to socialize with peers in free time (school trips, outings, celebrations, pocket money), they do not have the same opportunities as their peers who come from families with better financial status to realize their potential and their basic economic and social rights (KletečkiRadović, 2011; Elgar et al., 2013). This makes it difficult for them to realize their life goals, such as further education (McDonald, 2008), which leads to socioeconomic inequality. Therefore, child poverty cannot be defined only in financial terms because it affects different aspects of a child's life, which is why it is defined as multiple deprivation, material, school and social (Minujin et al., 2006; Ridge, 2009).

Living with chronic financial difficulties is stressful for both children and adults, and there are significant empirical evidence that material poverty of the family and facing insecurity and financial uncertainty has negative consequences for parents and children, especially if poverty is chronic and deep (Wadsworth and Berger, 2006; Katz et al., 2007; Martin et al., 2010). It has been found that children who live in poor families have more behavioral problems in adolescence and adulthood than their peers from wealthier families (Mystry et al., 2002; Rijlaarsdam et al., 2013). Although most studies link SES with behavioural problems of children, it seems important to underline the idea that it does not always have to be the case because of individual differences of children, and especially their parents who can reduce or eliminate the effects, and their skills and qualities (diligence, honesty, reliability) can improve outcomes of education and children's life opportunities, regardless of income, and thus impact both poverty and child's development (Martin et al., 2010). Therefore, good parenting can protect children from unfavourable socioeconomic effects (Katz et al., 2007).

Due to the fact that violence is a ubiquitous problem in schools around the world, there is a question, how much poverty and material deprivation affect the involvement of children in peer violence and if it predicts the role of a perpetrator and /or victim. Because of the importance, topicality and exposure of a large number of children to poverty and violence, the theoretical part of this paper analyzes the increase of peer violence in the context of socioeconomic inequalities in the communities of students and family factors, and the empirical part investigates which variables of socioeconomic status and material deprivation of children indicate a 
status of perpetrator or victim of peer violence.

\section{Peer violence}

Social relations and interactions with peers are key aspects in lives of children, especially adolescents. Those who manage to achieve and maintain satisfactory social relations with peers often behave prosocial and are less aggressive and violent. Despite the need for acceptance and importance of creating relations with peers, violence among them is increasing.

Peer violence can be defined as repeated aggressive behavior of one or more students who are physically stronger or psychologically or socially more powerful by intentionally causing physical, emotional or social damage to victims who cannot defend themselves (Olweus, 1998; Bilić et al., 2012). Basic elements used for defining peer violence - frequency, intention, consequences and helplessness of victims, differentiate it from peer conflict and abuse. Conflicts among peers are occasional negative actions which are based on misunderstandings, differences etc. If the conflicts are solved constructively, they become an opportunity to learn, otherwise, they turn into violence.

Violent behavior has different direct and indirect forms and is most often categorized as traditional (physical, verbal, sexual and relational) and electronic violence which is booming due to abuse of modern communication technology. Children of younger age and male gender are more prone to direct forms and girls and older children to indirect forms of violence (Elgar et al., 2009). Boys are more at risk of violent behavior (Olweus, 1998; Cook et al., 2010; Velki, 2012), and it is considered that violent behavior culminates in adolescence (Wang et al., 2009).

Results of international studies conducted on nationally representative samples in fourty countries show that $2-27 \%$ of children are perpetrators of traditional forms of violence and $4-28 \%$ are its victims (Craig et al., 2009), and variations are attributed to economic and cultural characteristics of individual country (Due et al., 2009). It is estimated that prevalence of electronic violence is $20-40 \%$ (Tokunaga, 2010; Hinduja and Patchin, 2014). Fu et al. (2012) provide evidence of all forms of violence increasing in the period from 1989 to 2009.

Maybe this is the reason why a large number of research deals with precisely the prevalence of violence, while factors which cause it are somewhat neglected (Frutos, 2013). Recent studies, as a framework for peer violence, use Bronfenbrenner ecological model which integrates different influences from the environment, but research most often focuses on analyzing individual characteristics of children, 
family and school variables. At the same time, contextual factors have not been thoroughly tested (Elgar et al., 2013) and unjustifiably ignored, although Cook et al. (2010) point out that they have a significant overall effect on violent behavior. Unfavourable social and macroeconomic environment can be a risk factor for behavioral problems and probably, violence. Some authors suggest (Boyer, Halbrook, 2011) that these problems can be understood as reflection of conditions in which students nowadays live.

\section{The connection between socioeconomic factors with peer violence}

Participation of children in peer violence can be explained through socioeconomic inequalities in societies they live in and socioeconomic family factors (Jansen et al., 2012; Elgar et al., 2013).

\section{a) Socioeconomic inequality in society}

In order to test the contribution of macroeconomic environment to peer violence, Due et al. (2009) conducted research in 35 countries in Europe and North America which included 162,305 students of 11, 13 and 15 years of age. They found that societies with greater economic inequality have a higher prevalence of violent behavior and adolescents are at greater risk of violence and victimization. Authors concluded that differences between countries and schools show that violence is not "natural behavior" but is partly conditioned by the socioeconomic environment.

Pickett and Wilkinson (2007) found that income inequality in 21 rich countries correlates with percentage of young people who are victims of violence $(r=0.47$; $\mathrm{p}=0.001)$. Income inequality is described by Elgar et al. $(2013 ; 238)$ as structural violence because it creates distrust, reinforces intolerance, encourages differences and revenge. The authors point out that children internalize social norms and ideas that life does not revolve around equality and reciprocity, but power and domination, so they see violence as an effective way to be successful. The authors also consider school violence as a potential consequence of such social influences.

Results of the aforementioned research and studies are particularly important in understanding peer violence that happens nowadays.

\section{b) Family socioeconomic factors}

Socioeconomic status (SES) is a construct that includes different dimensions of social position - power, prestige, economic well-being, professional status (Conger et al., 2010). Out of many variables who contribute to it, the most common SES indicators are considered to be: material income, educational level and professional status of parents and although their individual contributions are not negligible, the fact is that they are usually complementary (Katz et al., 2007). 


\section{Bilić}

Low SES can affect the participation of children in violence in several ways. First of all, the family is of key importance in understanding violence because it transfers norms of behavior towards others (Jansen et al., 2012). In order to explain the mechanism that connects socioeconomic status of the family and consequences in children' development, the model of family stress is used (Conger et al., 2010; Martin et al., 2010). According to the model, poverty contributes to stress and psychological problems of parents and their interpersonal conflicts, which has negatively affects their behavior towards children (less sensible interactions and use of inappropriate educational methods) and finally leads to reduced well-being of children and emotional and behavioral problems (Mistry et al., 2009; Evans and Kim, 2013). In such families, children are exposed to chronic stress which has a negative impact on self- regulatory processes that help children cope with external requirements (Evans and Kim, 2013). Parents who are struggling to survive and working extra hours are less able to devote time to their children and give them love, resources and adequate control, lack of which is considered a risk factor in various behavioural problems of children (Jensen, 2009; Šimić Šašić et al., 2011). Some authors which Katz et al. (2007) refer to believe that only extreme deprivation can cause major changes in a way of raising children, while such changes have not been identified in the families that fall into the category of relatively poor. In contrast, economic power is associated with higher quality parenting (Šimić Šašić et al., 2011), although it is not always the case in practice.

\section{c) Material deprivation of students}

In school, lack of income leads to child sensing that they are deprived of something and that they do not have what other children have (Ridge, 2009). Because of social comparison to their peers, they begin to feel the difference and believe that everything is determined by money and others treat them as different or pity them (McDonald, 2008). Lack of clothing, necessary supplies etc. can have a profound impact on their daily interactions with peers (Ridge, 2009; Martin et al., 2010). Therefore, the objective situation, as well as the subjective experience of their family's adverse financial conditions, leaves a mark on their daily lives and social relationships. They usually feel inferior, can be isolated and excluded from various activities (Ridge, 2009), but also publicly humiliated, stigmatized and devalued. So feelings of fear, humiliation, rage, despair and anger (DružićLjubotina and Ljubotina, 2014), but also sadness, are their common reactions to perceived emotional trauma and shattered social relations (Ridge, 2009). Thus, in such school situations they can react in two ways: some will be angry and frustrated and respond aggressively, being at higher risk of committing violence (Jensen et al., 2012), and others, because of unfair life circumstances and feelings of helplessness, sadness, anxiety, depression etc. (Ridge, 2009; DružićLjubotina and Ljubotina, 2014) become passive, desperate and 
fatalistic, which often leads them into a position of victim. Studies that examined the connection between socioeconomic factors and involvement of children in violence have not given consistent results. Some argue that socioeconomic factors are not connected to violent behavior and victimization (Sourander et al., 2000) or that their effect is negligible (Kim et al., 2005). Recent studies give socioeconomic factors an important role in explaining violent behavior. Thus, Jansen et al. (2012) found that in comparison to children who come from families of higher SES, children coming from families with lower SES, are at greater risk of being involved in violence as either victims or perpetrators. Other authors concluded that materially deprived children are mostly victims of violence (Ridge, 2009; Jankauskiene et al., 2008; Due et al., 2009; Fu et al., 2012), while perpetrators usually come from families of higher SES (Jankauskiene et al., 2008).

Incentives for research of this problems were frequent media reports about selfless support of Croatian wonderful teachers who give up on part of their modest salaries to help the poorest students (see: Hot meal paid to her student by this humane teacher; GlasSlavonije; October 29th, 2014), but also news about children who are abused by their peers because of their living conditions (see: Girl beaten up because of being poor, then transferred to another school; 24 sata; May 9th, 2013). Due to general neglecting of the role of community factors in explaining peer violence and more prominent problems in this domain, we decided to research whether socioeconomic family factors and material deprivation predict the status of a perpetrator or victim in schools.

\section{Methodology}

The aim of this paper is to examine which variables of socioeconomic family status and material deprivation of students predict the status of a perpetrator or victim among peers.

According to the defined goal, the following research problems were set:

a) To identify the characteristics of socioeconomic status (SES) and material deprivation (MD) of the respondents

b) To determine the prevalence of victimization and involvement of the respondents in committing violence

c) To analyze the connection between SES and material deprivation with victimization and committing violence

d) To examine which variables of socioeconomic status and material deprivation are predictors of victimization and predicting violence among peers. 
We expect the results to confirm the hypothesis that adolescents living in economically unfavourable conditions and are materially deprived are at greater risk of being victims of peer violence.

\section{The respondents}

The study included a total of 610 respondents, slightly more girls (51.6\%) than boys ( $44.8 \%)$. The average age of students was 13.88 years $(\mathrm{SD}=0.73)$, while most of the respondents were 14 years old (49.2\%). The sample consisted of slightly more eighth grade students $(57.7 \%)$ in comparison to seventh grade students (42.3\%), and most of them attended schools in a city (67.5\%), compared to schools in the country $(31.5 \%)$. The average academic achievement of students in the sample was 4.13 ( $\mathrm{SD}=0.82$ ), with very good $(40.2 \%)$ and excellent (37.5\%) being the most common grades.

The research was conducted in twenty classes in both rural and urban areas, located in different parts of Croatia (eastern, northern, central and southern). Since different areas are at different levels of development and were hit differently by the crisis (unemployment, shutting down businesses, some were affected by war, some were not), which might have affected respondents differently, we selected schools in Bjelovar- Bilogora, Brod- Posavina, Split- Dalmatia, Vukovar- Srijem and Zadar counties and the city of Zagreb.

\section{The procedure}

Data were collected during spring 2015, through group testing in grades with prior approval of parents and principles and in compliance with all provisions of the Code of Ethics for research with children. Approximately ninety parents did not sign the consent for participation of children in this study although it was voluntary and anonymity was guaranteed. Some professional staff, who provided generous assistance in implementing the research, noted that those were mainly parents with poorer economic status. Students who participated in research were given general instructions on completing the questionnaire, noting that they can opt out at any time,however, no one chose to do so. But, there were some students who did not respond to questions about material income of their family, while it was indicative that they responded to other questions.

\section{Instruments}

1. General data questionnaire contained questions about: gender, age, grade, school location (urban, rural) and grade point average. 
2. Socioeconomic conditions of the family questionnaire consisted of questions about: who the child lives with, how many children are there in the family, where the family lives (house or a flat, tenants, with relatives) and how they assess their living conditions (unsatisfactory, average, excellent), if they have their own room or share it with brothers and other family members and if they own a computer. The second group of questions related to education (unfinished or finished primary school, middle school, college, university or higher), employment status (permanently employed, employed but not being paid, occasionally employed, unemployed, pensioners) and tangible benefits (social aid, less than 2,000 kn; 2,000-4,000 kn; 4,000-6,000 kn; 6,000-10,000 kn and more than 10,000 kn) of father and mother. One question was related to frequency of family vacations (never, once in a few years, once or twice a year) and chidren's fear due to unsatisfactory financial situation of the family.

3. Scale of material deprivation of the student was constructed for the purposes of this paper based on literature (McDonald, 2008; KletečkiRadović, 2011; Neubourg et al., 2014). After factor analysis, question "Do you get a warm meal at school?" was removed so the scale had 10 items. They examine how often parents can set aside funds for activities and needs of their children at school such as books, school supplies, tutors, and participating in activities that are paid additionally, but also clothes and shoes that are popular among students, and meet their social needs (trips, outings, birthday parties, pocket money, etc.). On a scale from one to four (1- never; 2 - very rare, it is hard for them to find funds; 3 - sometimes they can spare some money; 4- always, they provide me with everything I need with no problems), respondents assessed how individual statements relate to them. Possible score range is from 1 to 4 , where a higher score indicated a lower level of material deprivation.

4. Scale of peer violence was designed for this study on the model of similar instruments (Bilić, 2013), but unlike them, in this scale, causes of violent behavior were associated with socioeconomic conditions or material deprivation of students (example: Have you ever spread ugly and untrue stories about other children in class because they are poor or neglected?). The scale consisted of 9 particles which examined children's participation in committing physical, relational and electronic violence during the current school year, and the respondents have on the scale of three levels (1- never; 2 - sometimes; 3 - often) assessed how these claims refer to them. Possible scores ranged from 1 to 3 , in which a higher score indicated a higher frequency of aggressive behavior.

5. Victimization scale had a total of three particles which examined how often during the school year were the students exposed to physical, relational or electronic 


\section{Bilić}

violence of their peers because they differ from them by their socioeconomic status (example: Has someone from class called you ugly names and insulted you because you are different, wear more modest clothes, etc.?). Respondents also assessed on a three-degree scale (1-never; 2 - sometimes; 3 - often) if the statements relate to them. Possible scores ranged from 1 to 3 , with higher scores indicating a higher level of victimization.

\section{Results}

In order to respond to tasks set in our research, we conducted frequency, descriptive and correlation analysis, followed by multiple regression analysis, the results of which are presented below.

\section{The socioeconomic profile of the respondents}

Socioeconomic status of the respondents was analyzed for the purpose of fulfilling the first goal of the research. Most of the students live with their mother and their father $(85.2 \%)$, in a family with two children (they have one brother or sister; $36.7 \%)$, then family with three children (31\%), and the least of them live in a family with four or more children (23.4\%). Families of most students live in their own house or flat (89.7\%), and most of them estimate their housing conditions as average $(67 \%)$. In contrast, $6.6 \%$ of students live as tenants, $3.1 \%$ with relatives, while only $2.8 \%$ of students estimate their living conditions as bad.

More than half of respondents have their own room (62.3\%) or share it with a sibling $(35.2 \%)$, while $2.1 \%$ sleep in a room with several members of their family. Also, a large number of students have a computer, with $41.5 \%$ of them having their own personal computer, while others share it with other family members (49\%), and $8.7 \%$ do not have a computer.

Regarding their parents' education, most of them finished high school (47.5\% of mothers and $47.2 \%$ of fathers). $14.6 \%$ of students reported low level of their mothers' education, having completed only primary school (13.1\%), and some not even that (1.5\%). Low level of fathers' education has been reported by $11.5 \%$ of students (completing only primary school $-10.2 \%$, and $1.3 \%$ not completing primary school), while $21 \%$ of mothers and $22.1 \%$ of fathers completed colleges and faculties.

In terms of the employment status, respondents stated that most mothers and fathers have a full-time job (53.8\% of mothers and $68.9 \%$ of fathers), however, 
even $29.8 \%$ of mothers and $8 \%$ of fathers are unemployed or occasionally employed (11.6\% of mothers and $7.2 \%$ of fathers), and around $1 \%$ work but are not being paid. In the category of pensioners there are more fathers (10.3\%) than mothers (1.6\%). Regarding material income of parents, the respondents claimed that the most common amount of income of parents is between 2,000 and 6,000 kn (50.5\% of mothers and $48.9 \%$ of fathers). Some parents fall into category of poorest, receiving social aid (5.7\% of mothers and $5.1 \%$ of fathers), and those who have income less than $2,000 \mathrm{kn}(11.1 \%$ of mothers and $5.2 \%$ of fathers $)$. Some students said their parents have income above $6,000 \mathrm{kn}$ and more (11.6\% of mothers and $28.7 \%$ of fathers). It is interesting to note than in categories of unemployed and low paid there are more mothers, while fathers are better paid. However, even $21 \%$ of students did not answer the question about their mother's income, and $12.1 \%$ did not answer the question about the income of father. It is possible that some children really do not know exact details about the material status of the family, but it is possible that they did not want to declare themselves about it, because they did answer other questions. It is well known that children are ashamed of poverty and afraid of stigmatization so they often try to hide the conditions in which they live. It is possible that their parents are not telling them about their financial problems because they are trying to protect them and they also encourage them not to talk about it in order to avoid being identified as poor, because they are worried and aware about the negative connotations (McDonald, 2008; Ridge, 2009). Thus, the results show that the surveyed students estimated their housing conditions as average, and on the scale of material deprivation they assessed their status as good $(\mathrm{M}=3.18 ; \mathrm{SD}=0.52)$. McDonald (2008) warns about the tendency of poor children to describe their material situation as average, although they are aware of the difference.

Most students go on family vacation for at least a weak once a year (41.6\%), and slightly fewer students go twice a year or more often (33.8\%). However, 10.7\% of students have never been on a vacation with their family. About half of students reported they never fret over the financial situation of their family (49\%), while slightly less students claim they do it sometimes (43.8\%), and 6.6\% students fret over it often or very often.

\section{Descriptive indicators of victimization and committing peer violence}

According to the second task of the research, we analyzed frequency of victimization and participation of respondents in committing violence and the results are shown in Table 1. 
Table 1: Frequency of victimization and committing violence

\begin{tabular}{|c|c|c|c|c|c|}
\hline \multicolumn{3}{|c|}{ Committingviolence } & \multicolumn{3}{|l|}{ Victimization } \\
\hline & $N$ & $\%$ & & $N$ & $\%$ \\
\hline $\begin{array}{l}\text { Nevercommit- } \\
\text { tedviolence }\end{array}$ & 385 & $63,1 \%$ & $\begin{array}{l}\text { Werenevervic- } \\
\text { tims }\end{array}$ & 321 & $52,6 \%$ \\
\hline $\begin{array}{l}\text { Committedvi- } \\
\text { olence }\end{array}$ & 212 & $34,8 \%$ & $\begin{array}{l}\text { Werevictim- } \\
\text { sofviolence }\end{array}$ & 276 & $45,7 \%$ \\
\hline No answer & 13 & $2,1 \%$ & No answer & 13 & 2,1 \\
\hline
\end{tabular}

Those who committed violence or were victims are those who had total score on scales higher than 1, so they answered at least one question on the scale with sometimes. As seen in the table, one third of children (34.8\%) has at least once, during the school year, committed violence, and almost half (45.7\%) of them were victims of violence at least once, because they were different in terms of a weaker financial status.

\section{The connection of socio-demographic variables and material deprivation with victimization and committing peer violence}

In order to respond to the third task of the research, we conducted correlation analysis, and Table 2 shows correlation of demographic variables, SES variables and material deprivation with committing violence and victimization of the respondents. Correlations were not calculated on variables that relate to who the child lives with and where the family lives, since almost all students answered they lived with their mother and father (85.2\%) and in their own house or flat (87.9\%). Variables of material income of mother and father were not included because of the large number of responses missing (21\% and $12.1 \%)$. For the same reasons, these variables were also not included in regression analysis.

Table 2: Correlation of demographic variables and SES variables with committing violence and victimization

\begin{tabular}{|l|l|l|l|l|}
\hline & \multicolumn{3}{|l|}{ Committing violence } & Victimization \\
\cline { 2 - 5 } & $\mathrm{r}$ & $\mathrm{N}$ & $\mathrm{r}$ & $\mathrm{N}$ \\
\hline Gender &,$- 143^{\star *}$ & 575 &, 016 & 575 \\
\hline Age &, $083^{\star}$ & 593 &, $082^{\star}$ & 593 \\
\hline Grade &, $098^{\star}$ & 597 &, 062 & 597 \\
\hline $\begin{array}{l}\text { Location of } \\
\text { school }\end{array}$ &, 023 & 591 &,$- 108^{\star *}$ & 591 \\
\hline
\end{tabular}




\begin{tabular}{|l|l|l|l|l|}
\hline $\begin{array}{l}\text { Academic } \\
\text { achievement }\end{array}$ &,$- 121^{* *}$ & 593 &,$- 133^{* *}$ & 593 \\
\hline $\begin{array}{l}\text { Number of chil- } \\
\text { dren in family }\end{array}$ &, 036 & 595 &, 036 & 595 \\
\hline $\begin{array}{l}\text { Housing condi- } \\
\text { tions }\end{array}$ &, 005 & 592 &,- 053 & 592 \\
\hline $\begin{array}{l}\text { Having their own } \\
\text { room }\end{array}$ &,- 035 & 595 &, $091^{\star}$ & 595 \\
\hline $\begin{array}{l}\text { Having a com- } \\
\text { puter }\end{array}$ &,- 073 & 592 &, 065 & 592 \\
\hline $\begin{array}{l}\text { Education of } \\
\text { mother }\end{array}$ &,- 037 & 576 &,$- 166^{* *}$ & 576 \\
\hline $\begin{array}{l}\text { Education of } \\
\text { father }\end{array}$ &,- 017 & 565 &,- 075 & 565 \\
\hline $\begin{array}{l}\text { Work status of } \\
\text { mother }\end{array}$ &,- 033 & 584 &,$- 088^{*}$ & 584 \\
\hline $\begin{array}{l}\text { Work status of } \\
\text { father }\end{array}$ &,- 056 & 572 &,$- 180^{* *}$ & 572 \\
\hline $\begin{array}{l}\text { Frequency of go- } \\
\text { ing on vacation }\end{array}$ &, 037 & 595 &,$- 139^{* *}$ & 595 \\
\hline $\begin{array}{l}\text { Fear of financial } \\
\text { situation }\end{array}$ &, 047 & 594 &, $223^{* *}$ & 594 \\
\hline $\begin{array}{l}\text { Material depriva- } \\
\text { tion }\end{array}$ &,- 041 & 595 &,$- 249^{* *}$ & 595 \\
\hline
\end{tabular}

In terms of committing violence, demographic variables that are in statistically significant correlation are: gender $(r=-0.143 ; p<0.01)$, where boys are those who are being violent more often and age $(r=0.083 ; \mathrm{p}<0.05)$, where older children are acting violently more often, and grade $(r=0.098 ; \mathrm{p}<0.05)$, where eighth grade students act more violently than students in seventh gradeIt has also been determined that academic achievement significantly correlates with frequency of committing violence $(\mathrm{r}=-0.121 ; \mathrm{p}<0.01)$, where students with poorer academic achievement are being violent more often. Even though all aforementioned correlations are very low, they are all statistically significant. However, the results show that none of the SES variables or material deprivation variables has a statistically significant correlation with committing violence.

When it comes to victimization, demographic variables that are in statistically significant correlation are: age $(\mathrm{r}=0.082 ; \mathrm{p}<0.05)$, where older children are being victims of violence more often and academic achievement $(\mathrm{r}=-0.133 ; \mathrm{p}<0.01)$, and 


\section{Bilić}

those who are less successful are victimized more often. The results shown in Table 2 show that students from schools in rural areas are victimized more often than students from schools in urban areas $(\mathrm{r}=-0.108 ; \mathrm{p}<0.01)$. As for the connection between variables of SES and victimization, it was found that children who are more often victimized are those who do not have their own room $(r=0.091 ; p<0.05)$, whose mothers have lower level of education $(\mathrm{r}=-0.166 ; \mathrm{p}<0.01)$, and whose mothers $(r=-0.088 ; \mathrm{p}<0.05)$ and fathers $(\mathrm{r}=-0.180 ; \mathrm{p}<0.01)$ have lower employment status. Children who go on family vacation less frequently are also being victimized more often $(r=-0.139 ; \mathrm{p}<0.01)$, together with children who demonstrate more fear because of financial status of the family $(r=0.223 ; \mathrm{p}<0.01)$. Material deprivation also correlates on a statistically significant level with victimization, where children who are more materially deprived are also victimized more often $(\mathrm{r}=-0.249 ; \mathrm{p}<$ $0.01)$.

\section{The results of regression analysis}

To determine which variables of socioeconomic status and material deprivation predict victimization and committing violence, we conducted regression analysis. Table 3 shows the results obtained in regression analysis with SES variables being predictor variables. Together with SES variables, analysis included demographic variables as control variables and only variable not included was grade because of large conceptual overlap with the variable age.

Table 3: Results of regression analysis with SES variables as predictors

\begin{tabular}{|l|l|l|}
\hline Criteria $>$ & Committing violence & Victimization \\
\hline Predictor & $\beta$ & $\beta$ \\
\hline Gender &,$- 128^{\star *}$ &, 031 \\
\hline Age &, 034 &, 054 \\
\hline Location of school &, 038 &,- 037 \\
\hline Academic achievement &,- 070 &,- 053 \\
\hline Number of children in family &, 042 &,- 003 \\
\hline Housing conditions &,- 035 &,- 008 \\
\hline Having their own room &,- 077 &, 045 \\
\hline Having a computer &,- 065 &,- 001 \\
\hline Education of mother &,- 010 &,$- 160^{\star *}$ \\
\hline Education of father &, 008 &, 097 \\
\hline Work status of mother &,- 005 &, 015 \\
\hline Work status of father &,- 034 &,$- 111^{\star}$ \\
\hline
\end{tabular}




\begin{tabular}{|l|l|l|}
\hline Frequency of going on vacation &, 077 &,- 025 \\
\hline Fear of financial situation &, 087 &, $182^{\star *}$ \\
\hline $\mathrm{R}$ &, $225^{\star}$ &, $331^{\star *}$ \\
\hline $\mathrm{R} 2$ &, $051^{\star}$ &, $110^{\star *}$ \\
\hline $\mathrm{N}$ & 501 & 501 \\
\hline
\end{tabular}

${ }^{*} p<0,05 ;{ }^{* *} p<0,01$

None of the independent SES variables analyzed in this paper has shown to be a predictor of committing peer violence, and when it comes to demographic variables, only gender has shown to be a predictor for committing violence at school, with boys being more likely to behave violently compared to girls $(\beta=-0,128 ; \mathrm{p}<$ 0,01 ). This set of predictors (SES and demographic variables) explained $5.1 \%$ of total variance $(\mathrm{p}<0.05)$ of committing peer violence.

In terms of SES variables, education of mother $(\beta=-0,160 ; p<0,01)$, work status of the father $(\beta=-0,111 ; \mathrm{p}<0,05)$ and fear over financial situation $(\beta=0,182$; $\mathrm{p}<0,01)$ are independently significant in predicting victimization in school, and the respondents whose mothers have lower level of education, whose fathers have poorer work status and who fear over financial status in the family more often, are also being more victimized. Out of demographic variables, none predict victimization independently. This set of predictors (SES and demographic variables) explained $11 \%$ of total variance $(\mathrm{p}<0.01)$ of victimization.

Table 4: Results of regression analysis with the variable of material deprivation as predictor

\begin{tabular}{|l|l|l|}
\hline Criteria $->$ & Committing violence & Victimization \\
\hline Predictor & $\beta$ & $\beta$ \\
\hline Gender &,$- 115^{* *}$ &, 068 \\
\hline Age &, 068 &, $083^{\star}$ \\
\hline Location of school &, 021 &,- 066 \\
\hline Academic achievement &,$- 085^{\star}$ &,$- 095^{\star}$ \\
\hline Material deprivation &,- 031 &,$- 253^{* *}$ \\
\hline $\mathrm{R}$ &, $182^{* *}$ &, $310^{* *}$ \\
\hline $\mathrm{R} 2$ &, $033^{* *}$ &, $088^{* *}$ \\
\hline $\mathrm{N}$ & 562 & 562 \\
\hline
\end{tabular}

$$
{ }^{*} p<0,05 ;{ }^{* *} p<0,01
$$




\section{Bilić}

According to results obtained in regression analysis, shown in Table 4, material deprivation independently does not significantly predict committing peer violence, and when it comes to demographic variables, gender $(\beta=-0,115 ; \mathrm{p}<0,01)$ and academic achievement $(\beta=-0,085 ; \mathrm{p}<0,05)$ have independently and significantly predicted committing violence. More violent groups are boys and students with poorer academic achievement. This set of predictors (material deprivation and demographic variables) explained $3.3 \%$ of total variance of committing peer violence.

Material deprivation independently predicted victimization $(\beta=-0,253$; $p<$ 0.01 ), with respondents with lower level of material deprivation more often being victims of their peers. Demographic variables of age $(\beta=0,083 ; p<0,05)$ and school achievement $(\beta=-0,095 ; p<0,05)$ independently predict victimization on a significant level, with older children and those with poorer academic achievement being more often victimized. This set of predictors (material deprivation and demographic variables) explained significant $8.8 \%$ of total variance $(\mathrm{p}<0.01)$ of victimization.

In conclusion, it should be noted that the examined variables explain a relatively small proportion of the variance in peer violence, which suggests that in order to explain this phenomenon, other individual and contextual factors and their interactions also need to be examined.

Discussion

The results show that a third of respondents (34.8\%) acted violently at least once during the school year, and almost a half (45.7\%) have in the same period experienced violence from their peers. Along with the fact that the obtained results are consistent with the findings of many other studies (Craig et al., 2009; Tokunaga, 2010; RajhvanBulat and Ajduković, 2010; Fu et al., 2013, Hinduja and Patchin, 2014), they also warn of the extent of the problem of peer violence in school regardless of different operational variables and determine the intervals at which the violence occurs (weekly, monthly, yearly). The results suggest that in relation to cited studies, there has been an increase in violence, and since the number of violent incidents is growing steadily, there are fears that the problem is getting out of hand (Fu et al., 2012; Frutos, 2013), despite various prevention programs. But the uniqueness of this research is that questions did not refer to total violence among peers, but to violence which is caused by material status of an individual student. In this respect, these data are indicative and worrying. Although peer violence is manifested and analyzed in terms of schools, it certainly exceeds them, so the results of this study need to be seen beyond them, or in a broader context. In addition, what must not be left out is the more prominent general inequality in contemporary society, which 
very likely affects the behavior of children who actually imitate adults (Due et al., 2009). It is possible that nowadays they internalize preferred behavior that is only aimed at success, at all costs, and are based on aggression, power and domination, and ultimately encourage differences, distrust, hostility and violence (Pickett and Wilkinson, 2007; Elgar et al., 2013). Literature (Jansen et al., 2012) suggests that in explaining participation of children in bullying, socioeconomic inequalities should be taken into account. Starting from that framework, this study analyzes peer violence as a reflection of specific socioeconomic family conditions which the child lives in.

As for the perpetrators of violence, the mentioned finding that one third of the respondents act violently towards their colleagues who are different bysocioeconomic characteristics (modest clothing, shoes, noticeable lack of financial resources) needs to cause concern. Even more so, data was collected by personal testimonies, and students have the tendency to give socially acceptable answers and sometimes they do not see their behavior as violent but as a joke, entertainment, especially that which is happening in the virtual world. The results of the conducted research show that the perpetrators of violence are often male students, of poor school achievement and those that are older, so male students with poorer school achievement are also predictors for committing violence.

Although perpetrators of violence are both girls and boys, in this, as well as in other studies (Cook et al., 2010; Velki, 2012; Beran, 2012; Fu et al., 2012; Elgar et al. 2013), it was found that boys, in comparison to girls, are more numerous in the category of bullies and are at greater risk for committing violence. This result can also be explained by the influence of a wider social environment in which show-offs of male strength are still tolerated, encouraged and generally considered acceptable behavior for boys (Beran, 2012). In accordance to social stereotypes, boys want to be seen as strong and powerful, whom others admire, especially girls. Some authors (Edgar et al., 2013) see violent behavior of boys as an attempt to maintain their social status in an unjust society. This particularly becomes evident in adolescence, when they fight for their position, dominance and popularity in the classroom.

The finding that the perpetrators of violence are often older students and eighth-grade students, was expected and consistent with the results of similar studies (Olweus, 1998; Velki, 2012), which confirms that older boys show more violent behavior.

The result that poorer school achievement correlates, but is also a statistically significant predictor for committing violence, is quite expected and in line with 


\section{Bilić}

other research (Olweus, 1998) which explain violent behavior as a reaction for failure in school. But according to results of this research, poorer school achievement is associated with victimization, which is also confirmed by other studies (Glew et al., 2005; Holt et al., 2007). Thus Glew et al., (2005) reported that 90\% of victims of peer violence have lower grades, one third have problems concentrating, and they also experience feelings of fear and anxiety, all of which can have an adverse effect on their academic results. In explaining the relation between poor academic achievement and victimization, it needs to be noted that nowadays, in culture that is focused on success at all costs, students who have poorer academic results are often exposed to mockery, ridicule, insults, exclusion from school activities, meaning non- physical, but also physical forms of violence. Embarrassment and violence they experience results in stress that hinders their school functioning and has a negative impact on their school success. People generally have a tendency to avoid embarrassing situations to students who experience such situations, and especially because of feeling of insecurity, children start skipping classes. Sense of insecurity at school and unjustified absenteeism have a devastating effect on school performance. Therefore, the correlation between academic achievement and violence is multi causal - lower success may be the cause of violence, but also its consequence, which again encourages bullying. On the other hand, academic achievement can be a protective factor from a series of problems in behavior of students and even violence. Therefore, in preventive school programs, strategies which allow every child to achieve success, according to their individual capabilities, must have a central place.

Analysis of connection between demographic variables with victimization also showed that there are more victims of peer violence in schools in rural areas, which can be explained by the fact that in such areas, people know more about living conditions of others, and children from such background are more sensitive to stigmatizations and differences (Ridge, 2009).

The conducted analysis shows that none of the SES variables, as well as material deprivation, does not correlate with committing violence, nor predicts it, and similar results were stated by Sourander et al. (2000). It seems that in relation to SES, other variables, such as family cohesion and interaction and parental actions (Šimić Šašić et al., 2011) have a significant role in violent behavior toward peers. And when it comes to victims of violence, a large number of recent studies (Ridge, 2009; Jankauskiene et al., 2008; Due et al.,, 2009; Fu et al., 2012) suggest a connection between socioeconomic situation of the family and victimization of the child, which is also supported by the results of this research. 
It is interesting that almost all SES variables that imply that a family is poor (child not having its own room, mother has lower level of education, mother and father have a lower work status, family rarely goes on vacations, children fearing family financial situation) are correlated in a statistically significant way with victimization. Although correlations are not high, they are indicative and statistically significant. Some of these variables independently predict victimization significantly, meaning that respondents whose mothers have a lower level of education, whose fathers have a lower work status and who fear financial situation in the family are also victimized more often. Material deprivation is also a significant predictor of victimization. This also confirms the research hypothesis that adolescents living in economically disadvantaged conditions as well as materially deprived are at greater risk of being victims of peer violence.

As previously mentioned, a part of respondents in this study did not answer questions about material income of parents, so it could have affected results because it is an important indicator of SES, but when it comes to disadvantaged children, it should be noted that it cannot be reduced to only income indicators, but an equally important role is also give to other factors such as education and employment of parents (McDonald, 2008).

Employment of parents is taken as an important indicator of SES because it is a relatively stable category which indirectly indicates earning (economic status) and non-economic, social characteristics, such as prestige etc. (Jansen et al., 2012). Lower level of education of a mother, who in our, still traditional culture, still takes more care of the child's education and spends more time with the child, indicates insecure employment, low income and disadvantaged social positions, and is associated with quality of parenting. Katz et al. (2007) point out that mothers with lower level of education provide less support (emotional, social, instrumental and information), use inappropriate educational methods etc. Children who receive no emotional support from their parents feel alienated, unhappy, sad, which all leads them into a position of a victim of peer violence. Other studies confirm that low level of education of parents increases the risk of victimization twice (Nordhagen et al., 2005).

Fathers are still seen as breadwinners, and their work status is considered a direct information on the social and economic status of the family, and according to this research results, it is also a predictor of victimization. Correlation was also found between mother's and father's work status with victimization of children. Mothers, and especially fathers who are unemployed or work but are not being paid 


\section{Bilić}

or are only occasionally employed, are in an unenviable situation and are exposed to stress. Not surprisingly, they are irritable, frustrated, demoralized and have difficulties coping with feelings of powerlessness and failure. Such condition is followed by despair, hopelessness, numbness, and eventually depression (Katz et al., 2007). It is therefore more difficult for them to focus on needs of a child and adequately respond to them (Jensen, 2009; Conger et al., 2010; Martin et al., 2010) even when they want to. Crisis family situations can reduce the availability of parental sensitivity and often lead to inappropriate, angry, inconsistent reactions, even the use of harsh discipline. Thus children are exposed to example and stress. Ridge (2009) claims that if parents are under stress, their children are also likely to be. Katz et al. (2007:44) consider stress a fundamental mechanism that connects unfavourable financial situation with unfavourable outcomes. In addition to the fact that parents are their possible models whose passive behavior and feeling of helplessness they imitate, childrenare often victims of their harsh verbal and physical actions (Bilić et al., 2012). Violence begins at home and goes on at school, as well as the stress they are exposed to, while it is all multiplied with brutal acts from peers at school. What they experience in their parents' home, especially the feelings of rejection and sadness, they transmit to their school environment, which again leads them into a position of victim, but now of peer violence.

Another variable correlating with victimization is a lack of room, an intimate corner, which children perceive as a problem that prevents them from inviting their peers over and hanging out with them. In fact, they perceive their disadvantaged position through social relations, not only through material resources (McDonald, 2008).

An unfavourable material situation can especially be evident in school through lack of school supplies, books or difficulties in meeting social needs (school trips, pocket money, birthday parties, outings). These elements of material deprivation, as stated by children, bring them into unequal position in comparison to their peers. Not being able to follow trends (clothes, shoes, mobile phones, etc.) is a visible indicator of poverty and difference in relation to the group they belong to. The difference is also contributed by a lack of access to resources (activities that are important for success) which have a vital role in their well-being and makes it difficult for them to be what they can be (KletečkiRadović, 2011). Deprivation in on area causes deprivation in other areas too (Ridge, 2009), it affects their educational and life chances. This inability of individuals to realize their potential and rights (Elgar et al., 2013) is referred to as socioeconomic inequality.

Since all children, especially adolescents, have similar expectations and the 
need to compare themselves with others, those who have difficulties with their material and social reality, it is not simple or easy for them while doing so. On the one hand, it is for a personal feeling of being different, and on the other, it is peer pressure and relations. A sense of being different, inferior and deprived both emotionally and materially, personally affects them very hard and they are quite aware of the implications of such a situation (Ridge, 2009). Additionally, they think they are not likeable or worthy to be loved, which all cumulatively affects their feeling of personal value and emotional stability (Rohner et al., 2012). Such negative mental presentations determine their relations with others. They cannot trust others, are too sensitive to reactions of others and generally perceive their environment as an unsafe, threatening and dangerous place (Rohner et al., 2012). The main consequences are shame, sadness and fear of being different and excluded, which can be felt in all domains of child's functioning (Ridge, 2009). One should not also forget the fear and burden of a family situation, which was found, according to these research results, to be a correlate and predictor of victimization.

Inability to have clothes, shoes and mobile phones like others or go on trips with their families and classmates often results in discrimination, prejudice and social isolation (McDonald, 2008). Rejection and exclusion from the group and encouraging others not to be friends with them, is a form of relational violence which leaves devastating consequences. But, for the same reason, children are often exposed to verbal violence, ridicule, humiliation directly, and also electronically. Situations of physical violence are not rare either. So, because of socioeconomicinequality, students can be victims of multiple victimization (Holt et al., 2007), which, according to this research results, affects a large number of children, almost half of the respondents.

On the one hand, rejecting behavior often experienced in a family then strengthened in school, and on the other hand, disrespect, humiliation and open attacks on dignity, have serious consequences (Jensen, 2009; Ridge, 2009; Neubourg et al., 2014). They affect health (physical consequences), again affect social relation (relational consequences) and the child's behavior (behavioral consequences). They also have a negative effect on school life (passivity and lack of interest in school, week sense of belonging, poorer academic achievement, absenteeism). Most visible consequences are those in the emotional domain, and are associated with sadness, depression, hopelessness, despair, fear of marginalization, together with deep emotional trauma and development of depressive symptoms in adolescence. Studies which Jensen (2009) refers to confirm that poverty is a predictor of depression in adolescence. All of the above leads into a position of a victim who are described as timid, withdrawn, quieter, more cautious and sensitive, passive, submissive, suffer- 


\section{Bilić}

ing from lack of self-esteem and having a negative attitude towards themselves and their position, they feel ashamed and unaccepted, unattractive (Olweus, 1998 : 39).

Finally, it should be noted that not all children who grow up in materially unfavourableconditions show negative development outcomes (KletečkiRadović, 2011), and it depends on their individual characteristics, but also their parents' behavior. It is also necessary to repeat that many parents, in spite of their scarce material resources, behave in an appropriate and responsible manner (Katz et al., 2007), and raise their children with love and protect them from bad influence from the environment and even family problems.

\section{Limitations}

Although this research results are indicative, they still have methodological limitations. First of all, only one source of data was used, self-estimation, and more sources (parents, teachers) would probably generate a more objective image of the analyzed problems. In addition, not all data about material income of the family were obtained. Future researchers are suggested to form a composite variable of financial status of the family or poverty.

\section{Conclusion}

Contrary to expectations, at the beginning of 21st century, there is almost an imposition of the need to develop awareness of socioeconomic inequality and material deprivation and encourage understanding of everyday reality of a growing number of children and adolescents who live in poor financial conditions. Socioeconomic problems in family are even more evident at school through lack of school supplies and access to activities which most people consider necessary (sports, language learning etc.) and difficulties with fulfilling social needs of students (trips, outings, celebrations etc.). Deprivation in one area often causes deprivation in others so children, unlike their peers who come from families with better SES, do not have equal chances to develop their potential and rights and realize their life goals. In addition, because of everything mentioned above, they frequently experience embarrassment and violence from their classmates.

The fact that it is a widely spread problem is also confirmed by the results of a research which show that during one school year, one third of children (34.8\%) has committed at least once, and one half (45.7\%) experienced peer violence, because they are different by socioeconomic characteristics (more modest clothes, shoes, evident lack of financial resources). The problem of peer violence must be 
seen in the context of socioeconomic social inequalities, but as well as a reflection of specific socioeconomic family conditions which students live in.

Findings of this research show that adolescents who live in economically unfavourable conditions and are materially deprived are at greater risk of being victims of peer violence. It is interesting that almost all SES variables which indicate poor families (not having own room, mother has a lower level of education, mother and father have a low work status, the family rarely goes on vacation, children are afraid of the family financial situation) are in correlation with victimization. Some of them, in a statistically significant way, independently predict victimization, i.e. respondents whose mothers have lower level of education, whose fathers have a lower work status, who are materially deprived at school and who fear the family's financial situation more, are more often victims of peer violence.

At school, poor children are often associated with various embarrassing situations, such as mischief, fights, stealing, and contrary to this stereotype, our research results show that the analyzed SES variables or material deprivation do not predict committing violence.

Practitioners, general public and policy makers are suggested to pay attention and help a growing number of children from socioeconomically disadvantaged families. They need to be in focus of all school preventive programs, especially because of greater risk for them being exposed to peer violence. 


\section{References}

Bilić, V., Buljan Flander, G., Hrpka, H. (2012).Nasiljenaddjecom i međudjecom. Jastrebarsko: Naklada Slap.

Bilić, V. (2013).Moral sensitivity and peer violence: The role of empathy and caring.Sodobnapeda gogika, 64 (2), 48-65.

Bouillet, D. (ur.) (2002). Svijetdostojandjece. Zagreb: Državnizavodzazaštituobitelji, materinstva i mladeži.

Boyer, B. A. andHalbrook, A. E. (2011).Advocating for Children in care in a Climate of Economic Recession: The Relationship between Poverty and Child Maltreatment.Northwestern Journal of Law and Social Policy, 6 (2), 300-317.

Conger, R. D., Conger, K. J., and Martin, M. J. (2010).Socioeconomic status, family processes, and individual development.Journal of Marriage and Family, 72 (3), 685-704.

Cook, C. R., Williams, K. R. Guerra, N. G., Kim, T. E., Sadek, S. (2010).Predictors of Bullying and Victimization in Childhood and Adolescence: A meta-analitycal Investigation. School Psychology Quarterly, 25 (2), 65-83.

Craig, W., Harel-Fisch, Y.., Fogel-Grinvald, H., Dostaler, S., Hetland, J., Simons-Morton, B., Molcho, M., de Mato, M. G., Overpeck, M., Due, P., Pickett, W.(2009). A cross-national profile of bullying and victimization among adolescents in 40 countries.International Journal Public Health,54 (Suppl 2), 216-224.

DružićLjubotina, O. andLjubotina, D. (2014).Odnossiromaštva i nekihaspekatapsihološkedobrobiti. Socijalnapsihijatrija, 42 (2), 86-101.

Due, P., Merlo, J., Harel-Fisch, Y., Damsgaard, M.T., Holstein, B,E., Hetland, J., Currie, C., abhainn, S.N., de Matos, M.G., Lynch, J. (2009) Socioeconomic inequality in exposure to bully ing during adolescence: a comparative, cross-sectional, multilevel study in 35 countries. American Journal of Public Health, 99(5), 907-914.

Elgar, F. J., Pickett, K. E., Pickett W., Craig W., Molcho, M., Hurrelmann, K., Lenzi, M. (2013).School bullying, homicide and income inequality: a cross-national pooled time series analysis. International Journal of Public Health, 58(2),237-245.

Evans, G. and Kim, P. (2013). Childhoodpoverty, chronicstress, self-regulation, andcoping. Child DevelopmentPerspectives, 7(1), 43-48

Frutos, T. (2013).Five Independent Variables Affecting Bullying: Neighborhood, Family, School, Gender-Age and Mass Media. Sociology Mind, 3, 304-313.

Fu, Q, Land, K. C., Lamb, V. L. (2013). Bullying victimization, socioeconomic status and behavioral characteristics of 12th graders in the United States, 1989 to 2009: repetitive trends and persistent risk differentials. Child Indicators Research, 6(1),1-21.

Glew, G. M., Fan, M. Y., Katon, W, Rivara, F. P., Kernic, M. A. (2005). Bullying, psychosocial adjust ment, and academic performance in elementary school.Archive of pediatrics and ado lescent medicine, 159, 11, 1026-1031. 
Holt, M. K., Finkelhor, D., Kantor, G. K. (2007). Multiple victimization experiences of urban elemen tary school student: Associations with psychosocial functioning and academic perfor mance. Child Abuse and Neglect, 31, 503-515.

Jankauskiene, R., Kardelis, K., Sukys, S., Kardeliene, L. (2008). Associations between school bullying and psychosocial factors.Journal of social behavior and personality, 36,145-162.

Jansen, P. W., Verlinden, M., Berkel, A. D., Mieloo, C., Van der Ende, J., Veenstra, R., Verhulst, F. C., Jansen, W., \&Tiemeier, H. (2012). Prevalence of bullying and victimization among children in early elementary school: Do family and school neighborhood socioeconomic status matter? BMD Public Health, 12, 494.

Jensen, Eric. (2009). Teaching with Poverty in Mind: What Being Poor Does to Kids' Brains and What Schools Can Do About It. Alexandria, VA: Association for Supervision and Cur riculum Development.

Katz, I., Corlyon, J., La Placa, V. and Hunter, S. (2007).The Relationship Between Parenting and Poverty. York: Joseph Rowntree Foundation.

Kim, Y.S., Koh, Y-O, Leventhal, B. (2005). SchoolbullyingandsuicidalriskinKoreanmiddleschoolstu dents. Pediatrics, $115,357-363$.

KletečkiRadović, M. (2011).Siromaštvo i nekiaspektipsihosocijalnograzvojadjece(PhD disertation). Zagreb: PravnifakultetSveučilišta, Studijskicentarsocijalnograda.

Martin, M. J., Conger, R. D., Schofield, T. J., Dogan, S. J., Widaman, K. F., Donnellan, M. B. i Neppl, T. K. (2010).Evaluation of the interactionist model of socioeconomic status and problem behavior: a developmental cascade across generations. Development and Psychopatholn ogy,22(3), 695713.

McDonald, C. (2008). Children's lived experience of poverty: A review of the literature. Prepared by the ARACY Collaborative team undertaking the Children's Lived Experience of Poverty project, including. RMIT University, the NSW Commission for Children and Young People and The Benevolent Society.

Minujin A., Delamonica E., Davidziuk A. i Gonzalez E. (2006).The definition of child poverty: A discussion of concepts and measurements.Environment and Urbanization, 18(2), 481-500.

Mistry, R.S., Benner, A. D., Tan, C. .S, Kim, S.Y. (2009). Family economic stress and academic well-being among Chinese-American youth: the influence of adolescents' perceptions of economic strain. Journal of family psychology, 23(3), 279-290.

De Neubourg, C., M. de Milliano, I., Plavgo, Z. (2014). Lost (in) Dimensions: Consolidating progress in multidimensional poverty research, Innocenti Working Paper No. 2014-04, UNICEF Office of Research, Florence.

Nordhagen, R., Nielsen, A., Stigum, H., Kohler, L. (2005). ParentalreportedbullyingamongNordic children: a population-basedstudy.Child: Care, Health andDevelopment , 31(6), 693-701. Olweus D. (1998).Nasiljemeđudjecom u školi. Zagreb: Školskaknjiga.

Pickett, K. E., Wilkinson, R. G. (2007). Child wellbeing and income inequality in rich societies: eco logical cross sectional study. British Medical Journal, 335(7629), 1080-1086.

RajhvanBulat, L. i Ajduković, M. (2012).Obiteljske i psihosocijalneodrednicevršnjačkognasilja.Psi hologijsketeme, 21 (1), 167-194. 
Ridge, T. (2009). Living with Poverty: A Review of the Literature on Children's and Families' Expe riences of Poverty. Research Report No 594, Department for Work and Pensions, Norwich: HMSO.

Rijlaarsdam, J., Stevens, G. W. J. M., van der Ende, J., Hofman, A., Jaddoe, V. W. V., Mackenbach, J. P., Verhulst, F. C., \&Tiemeier, H. (2013). Economic disadvantage and young children's emotional and behavioral problems: Mechanisms of risk. Journal of Abnormal Child Psychology, 41(1), 125-137. Sourander, A., Helstelä, L., Helenius, H., i Piha, J. (2000).Persistence of bullying from childhood to adolescence-a longitudinal 8-year follow-up study.Child abuse and neglect, 24(7), 873-881.

Šimić Šašić, S. Klarin, M. i Proroković, A. (2011).Socio ekonomske prilike o bitelji i kvaliteta obitel jske interakcije kao prediktori školskog uspjeha srednjoškolaca u Hrvatskoj, Bosni i Hercego vini i Makedoniji. Ljetopis socijalnog rada, 18(1), 31-62.

Šućur, Z. (2006).Siromaštvo, više dimenzionalna deprivacija i socijalna isključenost u Hrvatskoj. Revija za sociologiju, 37 (3-4), 131-147.

Šućur, Z. (2014).Stari i novi siromasi u hrvatskom društvu: empirijski uvid. Bogoslovska smotra, 84 (3), 577-610.

Tokunaga, R.S. (2010). Following you home from school: A critical review and synthesis of research on cyberbullying victimization.Computer in Human Behavior, 26, 277-287.

Velki, T. (2012).Uloga nekih obiteljskih čimbenika u pojavi nasilja među djecom.Psihologijske teme, 21 (1), 9-6.

Wadsworth, M.E.andi Berger, L. E. (2006).Adolescents coping with poverty-related family stress: Prospective predictors of coping and psychological symptoms. Journal of Youth and Ado lescence, 35, 57-70.

Wang, J., Iannotti, R.J., Nansel, T. R. (2009). School Bullying Among US Adolescents: Physical, Verbal, Relational and Cyber. Journal of Adolescent Health, 45 (4), 368-375.

\section{Internet Resources:}

Beran, T. (2012) Bullying: What are the Differences between Boys and Girls? www.education.com/ reference/article/Ref_Bullying_Differences (accessedon5.11.2013).

Hinduja, S., Patchin, J. W. (2014). Cyberbullying fact sheet: Identification, Prevention, and Response. Cyberbullying Research Center. Retrieved [accessed in June, 2015], http://www.cyberbullying. us.dewaporn.com/Cyberbullying-Identification-Prevention-Response.pdf.

Rohner, R. P., Khaleque, A., Cournoyer, D. E. (2012). Introduction to Parental Acceptance-Rejection Theory, Methods, Evidence, and Implications. http://csiar.uconn.edu/wp-content/uploads/ sites/494/2014/02/INTRODUCTION-TO-PARENTAL-ACCEPTANCE-3-27-12.pdf, (accessed on 5. 7. 2015).

Swearer Napolitano, S. M. (2011).Risk Factor for and Ouctomes of Bullying and VictimizationEducational Psychology Papaers.www.http://digitalcommons.unl.edu/edpsyhpapers/132(accessed: 24. 06. 2014). 